Public Health of Indonesia

\title{
HOT BATH THERAPY FOR POSTPARTUM MOTHERS: THE ETHNOCARING PRACTICE IN THE MUNA TRIBE, SOUTHEAST SULAWESI, INDONESIA
}

\author{
Diah Indriastuti*, Tahiruddin
}

Nursing Science Program, STIKes Karya Kesehatan, Indonesia

\author{
Received: 18 November 2019 | Accepted: 14 December 2019 \\ DOI: http://dx.doi.org/10.36685/phi.v5i4.312 \\ Correspondence: \\ Diah Indriastuti \\ Nursing Science Program, STIKes Karya Kesehatan, Indonesia \\ J1. Jend AH Nasution No 89 Anduonohu, Kendari City, 93232, Indonesia \\ Email: nsiahindri@gmail.com
}

Copyright: (C) the author(s), YCAB publisher and Public Health of Indonesia. This is an open-access article distributed under the terms of the Creative Commons Attribution Non-Commercial License, which permits unrestricted non-commercial use, distribution, and reproduction in any medium, provided the original work is properly cited.

\begin{abstract}
Background: Postpartum mothers are vulnerable to postpartum fatigue, delivery process fatigue, and role transition. The unknown fatigue can trigger stress and anxiety that will lead to postpartum blues and postpartum depression. The ethnocaring of the Muna tribe has a series of care that can prevent postpartum fatigue, including a hot bath.

Objective: To explore the ethnocaring practice on the postpartum care method in the Muna tribe using hot bath and analyze it scientifically.

Methods: This study was a qualitative study with an ethnographic approach. The participants were 15 Muna's indigenous midwives and 4 Muna's mothers. Snowball sampling was employed to select the samples. The data were collected through indepth interviews, focus group discussion and participatory observation. The data validity was made by completing the trustworthiness criteria process.

Results: The results of the study were described into 3 themes, namely equipment, treatment, and prohibition. The equipment theme describes tools and materials.

Conclusion: The ethnocaring therapy of a hot bath in Muna's postpartum mothers has healthy benefits namely for relaxation, increasing the oxygen uptake, increasing concentration and revitalizing the reproductive organs.
\end{abstract}

Keywords: indigenous midwives, Muna tribe, culture, puerperium

\section{BACKGROUND}

Fatigue is major problem experienced by postpartum mothers. Physical change, hormone and joint transfer and wound during delivery are experiences that physically and mentally affect health (Girsang, Darti, Simamora, \& Karo, 2019; Kusumasari, 2018; Osma, SusoRibera, Martínez-Borba, \& Barrera, 2020; Saputri, Rahayu, \& Sri, 2016). Mothers often experience anxiety and stress due to fatigue and even experience baby blues and postpartum depression (Diah Indriastuti, 2015; Fatmawati,
2015; Gutira \& Nuryanti, 2010; Wijaya \& Arum Pratiwi, 2017).

Studies in the United States and the United Kingdom have shown that more than $10 \%$ of mothers experienced postpartum depression, while in Africa and Asia, this proportion was higher, 25-60\% (Corey \& Thapa, 2011; Thurgood, Avery, \& Williamson, 2009). The incidence of postpartum blues in several regions in Indonesia varies between $11 \%$ to 70 
$\%$ of all postpartum mothers (Kurniasari \& Astuti, 2015; Oktiriani, 2017).

Support from family members is one of the important factors to help postpartum mothers pass their transition period (Nasri, Wibowo, \& Ghozali, 2018; Wijaya \& Arum Pratiwi, 2017). These supports can be informational support about how to do a self and baby care, instrumental support such as providing mother's and baby's need, emotional support by understanding mother's problem, and assessment support by caring about mother's weakness (Gutira \& Nuryanti, 2010; Kurniasari \& Astuti, 2015).

Family support ethnically becomes a habit as the form of knowledge and technology over times (Rahayu, Mudatsir, \& Hasballah, 2017). The postpartum cares such as consuming herbs, using abdominal sash, massage, and steam bath have been studied previously as a form of family support for generations (Fitrianti \& Angkasawati, 2015; Marzuki; Prastiwi; Usman \& Sapril, 2018).

The technology of postpartum health care attributed to a community for generations or ethnocaring of the Muna tribe takes care of the postpartum mothers by indigenous midwives. One of the caring steps is a hot bath. A preliminary study in 6 mothers experienced postpartum said that the postpartum care was done by having a hot bath. In the beginning, the mothers felt afraid, however by the support from their mother, mother-in-law, and indigenous midwife who took care of them, the postpartum mothers believed that a hot bath will be healthful if they comply and feel the advantage subsequently.

A study about bath therapy has been done before on different tribes and samples, namely Butonese, showed that postpartum bath therapy is beneficial for vitality and health recovery also preserving ethnocaring (Usman \& Sapril, 2018). This study aimed to explore the ethnocaring practice on postpartum care method in the Muna tribe using a hot bath and analyze it scientifically.

\section{METHODS}

Study design

This was a qualitative study with an ethnographic approach, a study that elaborates on the life pattern and to understand a culture or habit attributed to a certain social group (Afiyanti \& Rachmawati, 2014; Siswanto, 2017).

\section{Setting and sample}

The study was carried out in the Muna tribe community in Kendari; Abeli, Gunung Jati, Mangga Dua, Jambu Lane, Kancil Lane, Banteng Lane, Kawat Lane, Poasia and WuaWua from July to October 2019. The populations were all the Muna tribe indigenous midwives. The samples were 15 indigenous midwives and triangulation participants were 4 Muna tribe mothers who experienced ethnocaring. The number of participants was expected to help the data saturation process, especially for the participatory observation process. This was due to the rules forbidding the home-delivery process that make the indigenous midwives lost their patients, and thus the researcher had to increase the number of key participants to anticipate if the indigenous midwife could not find patients for a long period.

\section{Instrument}

Data were collected using structured interview guided by interview guidelines through an indepth interview, however, the researcher did not restrict the data collection method. The focus group discussion can be made if the indigenous midwives have lived and shared their indigenous caring knowledge for generations. The participatory observation is a method used to obtain a clear definition of the study's aims. Field note is used to record the field observation. The sampling technique used snowball sampling.

\section{Data analysis}

Data were analyzed using the Nvivo 12 application by conducting thematic analysis. Trustworthiness is carried out by doing credibility, transferability, dependability and confirmability (Afiyanti \& Rachmawati, 2014). 
Credibility through member checking and thick description preparation, as well as triangulation. Triangulation carried out by researchers is by conducting in-depth interviews of participants' triangulation, observation and participation of researchers. Transferability by conducting interviews with Muna Sando who live in urban areas of the City of Raha. Dependability is done by making structured data analysis and interpreting the results correctly. Confirmability is done by reflecting findings with related journals, repeated information from participants and consultation with experts.

\section{Ethical consideration}

The ethical clearance was approved by IAKMI Southeast Sulawesi Regional Board number 01/KEPK-IAKMI/V/2019.

\section{RESULTS}

Figure 1 explains that the age of the oldest participant is 90 years, the occupation of most participants is housewife and the location of research with the most participants is in Gunung Jati.

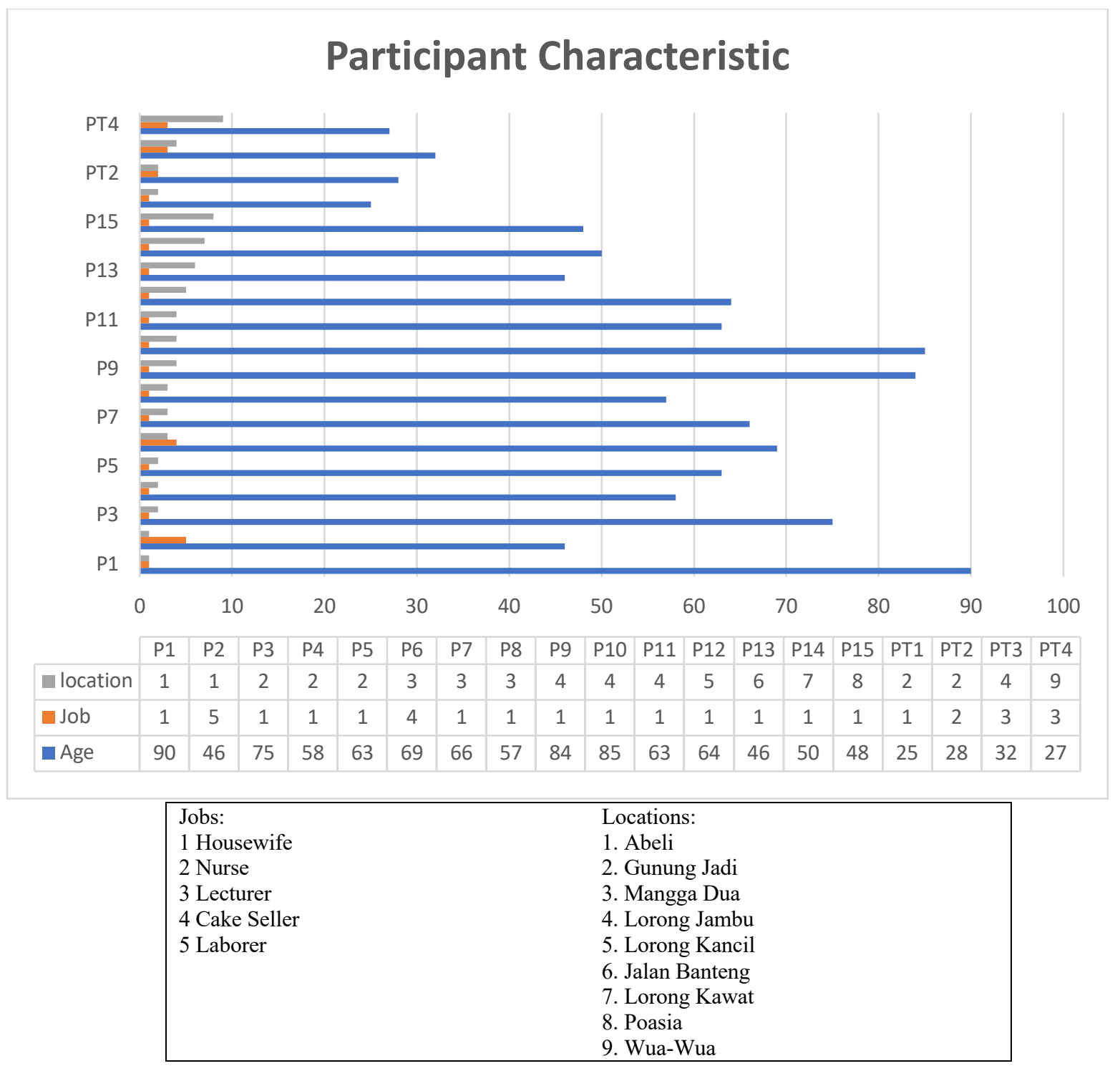

Figure 1 Participant's characteristic 
The results of the study were described into 3 themes, namely equipment, treatment, and prohibition.

\section{Treatment}

The treatment theme was identified through the time, duration and procedure categories. The time category was described with the keyword after and immediately through the following statements:

"....long time ago, after the baby was born the mother was immediately bathed, ... 2 days after being discharged from the hospital......"(P1\&2)

"...after being discharged from the hospital, after 2 days of delivery ...."(P11)

“... long time ago, the mother gave birth immediately treated ... after returning from the hospital, the next day I came to give the bath treatment... "(P5)

"...if in the past Yes, I immediately left..."(P6)

“...In the old days immediately took a hot bath...”(P8)

"...if I have been called to the house immediately take care of the bath ... go straight there..."(P9)

"...wait to be discharged from the hospital after 2 days and then given a bath.."(P12)

The participant statement was reinforced by the following triangulation participant statement:

"....if the patient gives birth at home immediately take a hot bath, if at the hospital wait after discharge...'(PT1)

The duration category was described with the keyword day and week through the following statements:

“...given a bath 40 days, use hot water ... 2 times 1 day ... 20 days hot water, 20 days the water is half hot...."(P1\&2)

“...40 days of boiling hot water ... twice a day...”(P3)

“...usual 3 months or 120 days...”(P4)

“...7 days or a week bathed...”(P5)

“... Ee at most I take seven days ... the mother takes her bath alone when I finish the seven days and she bathes with hot water..".(P6)

"... Haa finished, oh seven days finished, finished the bath for seven days..."(P7)

"...One week, especially if the first child was until usual nine days, there are nine days required,..."(P8)

“...4 days if 1 time a day, 2 days if 2 times a day..."(P9)

"....give a bath after 1 day being discharged from the hospital ... 4 times, 4 times 2 days, 1 time morning 1 time afternoon ...... "(P10)

“...take a hot bath after giving birth 2 days, 1 time 1 morning 1 time...(P11)

"...the bath 4 days, morning afternoon, 8 times...(P12)

"...week, if the second child 4 days, all morning afternoon, use hot water...(P13)

... usually people take bath care 2 days, 2 times a day, morning...(P14)

... 4 times, take a bath, 2 days...”(P15)
The participant statement was reinforced by the following triangulation participant statement:

“...One day twice to 1 week...”(PT1)

“....hot water, morning and evening ... the first day until the seventh day..."(PT3)

"...hot water for 3 months, every day 3 times bathing (morning, afternoon, evening)....” (PT4)

The procedure category was described with the keyword press $_{2}$ spell $_{2}$ and Islamic invocation through the following statements:

“.....after that pressed down...("P1\&2)

“...cast a spell for hot water...”(P3)

"...to the mother's body by pressing quickly and repeatedly ... there is that special Islamic invocation..." p4)

"...pressed like this using a cloth ... before treating a bath, first a spell..."(P5)

“...pressed down...”(P6)

“...I just press it like this ... pressed a little ... there is a spell...”(P7)

“...Yes, because we have our stomach pressed, not hard, but we set it....”(P9)

“.....the stomach is pressed with cloth..."(P10)

“...pressed ... pressed the body....”(P13)

"...after that this side is strengthened, pressed here..."(P14)

"....so I press it hard ... dip it in hot water and just press it...”(P14)

“... put on pressed cloth...."(P15)

The participant statement was reinforced by the following triangulation participant statement:

“...If you press it, it comes out dirty blood..."(PT1)

"...there is an ordinary eee spell ... that's why this area is suppressed... "(PT2)

"...then emphasize the area of the uterus below ...... with the spell too... "(PT3)

"...dipped first then pressed on the body .... then pressed on the birth passage...”(PT4)

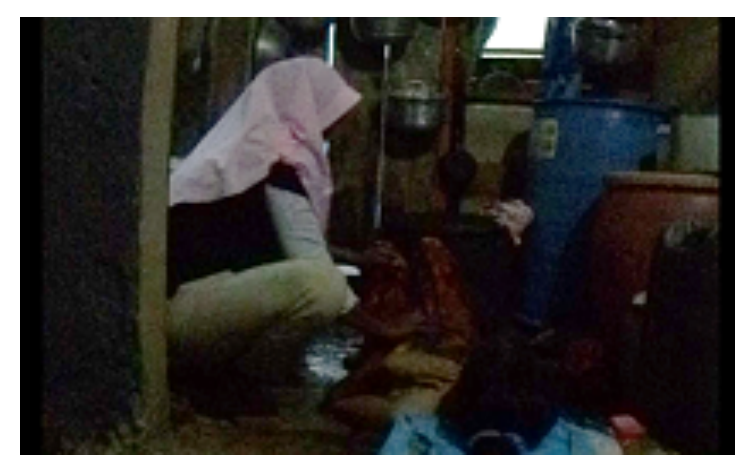

Figure 2 Postpartum mother in reclining position receiving therapy from sando using a cloth by pressing on the abdomen, legs, hands, back and face

The benefit category was described with the keyword So through the following statements: 
"...give hot water first so that the blood will come out later..."(P3)

"...so as not to get sick ... give the mother a bath again so that the broken veins become connected again..."(P4)

"...so that ee is vein e the blood that is retained and comes out ... then for the face of the mother to be treated as well so that she is in harmony ... so that she feels good again..."(P6)

"...so that dirty blood comes out, which if left inside can become a disease..."(P7)

"...so that there is no blood in it ... the veins break up because they push, so they come back, they dry quickly with ... take a hot bath so they get healthy again quickly..." (P10)

"...in order to help the dirty blood from the remnants of blood to come out heem ... neck due to fear of enlarged glands, later it can hurt mumps, then if the back of the back so it Is not easy to get headaches, so that there is no accumulation of fluid in the face, eyes usually after giving birth because it is too strong to push, the mother's eyes turn red, shoulders, especially if there is no breastmilk, so this must be given hot water in the breast......"(PT2)

"...so it can return the birth canal as before..."(p11)

"...to be healthy ... stomach so the uterus will heal, dirty blood comes out...”(p12)

“...deep wounds, swollen veins to heal ... so that they shine, so they don't turn pale, not yellow ... so that the womb is well again..."(p14)

"...take a hot bath so the body will fell fresh,..."(p15)

The participant statement was reinforced by the

following triangulation participant statement:

"...take a hot bath so that the body doesn't get sick..."(PT1)

“...so as not to become headaches...'(

"(PT2)

\section{Equipment}

The equipment theme was identified through the tool and material categories. The tool category was described with the keyword hot water through the following statements:

"... after the mother gave birth, I immediately made hot water right away ... immediately bathed as soon as the baby came out, the hot water was immediately raised above the kitchen ... bathing the mother for 40 days, using hot water ... but a hot bath ... boiling water, adjusted the heat ..." ( P1 \& 2)

"... the bath is hot water ... just use hot water ... a cloth soaked in the hot water a little with the cold water must also ... mixed with cold water if not the hot water can make people die ... one cauldron water. ... "(P3)

"... the one who gave birth after being given a hot bath, her mother felt lightness in her body, bathed with water that was not too hot ... hot water was then given to the body ... hot water stops or freezes blood ..." ( p4)

"... taking a hot bath, pressing like this using cloth ... the hot water is mixed with a little cold water ..." (P5) "... the hot water is ready ... immediately $\mathrm{i}$ bring it to the bathroom and a cast the spell, ready hot water ... basically all the body is flush ... if the same face is the last order ... hot water, hot water.. mixed with cold water a little two bucket or three bucket ... (P6)

"... I give hot bath therapy for only one week haaa ... I also add cold water to the hot water, yeah it's hot anyway ..." (P7)

"... ......after giving birth, I give hot bath therapy ... take a hot bath right away ... yes I add cold water ... the important thing is I can still put my hands in the hot water, if the mother screams too, I say: don't you shout, this treatment is cured ... (P8)

"... just being given a bath of hot water ... depends on the mother who gave birth after she wants to heat or she wants the water mixed with cold water ..." (P9)

"... boil, boil, the bath water is mixed with cold water that is just not too hot, not too cold ... just take a hot bath until the white blood comes out ... take a hot bath so that the body gets healthy again .... . "(P10)

"... the hot water for bathing is mixed ... if the mother finishes giving birth, still use hot water ..." (P11)

"... after giving birth, take a bath first, use hot water, the limit of the heat are can be touched to ... use hot water mixed with cold water ... (P12)

"... I heated up the water, I gave the mother's mandimi with boiling hot water ... that was hot water I did not mix ... hot bath therapy that gave benefits to the veins ... the bath water was cast a spell. .. (p14)

"... take a hot bath ... take a hot bath so that the body returns to fresh ......" (P15)

The participant statement was reinforced by the following triangulation participant statement:

"... after childbirth, they are usually given a hot bath all the time ... It's really hot ... Wow, I feel afraid if I will be given a bath treatment, it looks like what we are afraid of because it uses a twenty liter pot of hot water ... "(PT2)

"... bathing hot water ... (PT1)

"... hot and only slightly mixed with cold water, from the extra large pot ... in addition to only 3 bails of cold water ... when bathed in hot water, I feel very ... very hot when exposed to hot water again, but must be maintained ..." (PT3)

"... Yes, hot bath treatment using hot water ... boil it right and only mixed with 1 dipper water ... (PT4)

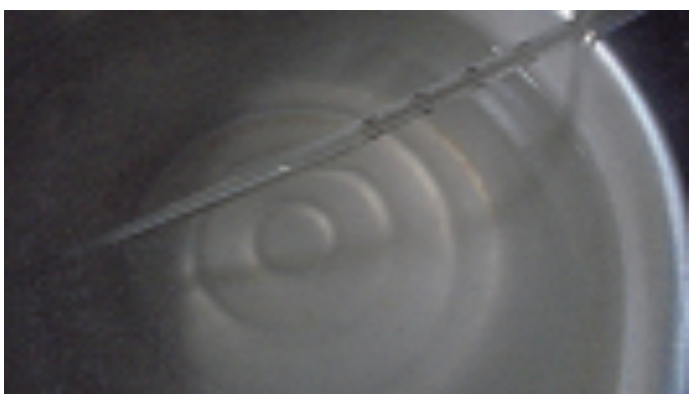

Figure 3 Measurement of the temperature of water that has just boiled with a temperature of $80^{\circ} \mathrm{C}$ and can not be touched by the hand 


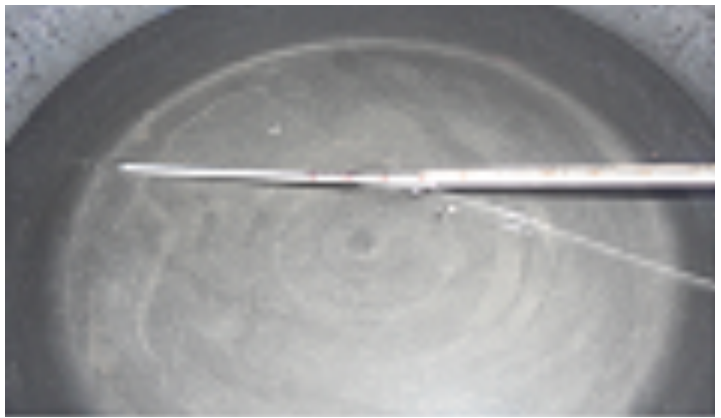

Figure 4 Measurement of temperature in boiling water temperature of $80^{\circ} \mathrm{C}$ that has been mixed with plain water until it can be touched by hand with a temperature of about $50^{\circ} \mathrm{C}$. Water feels still hot but can be tolerated to be held

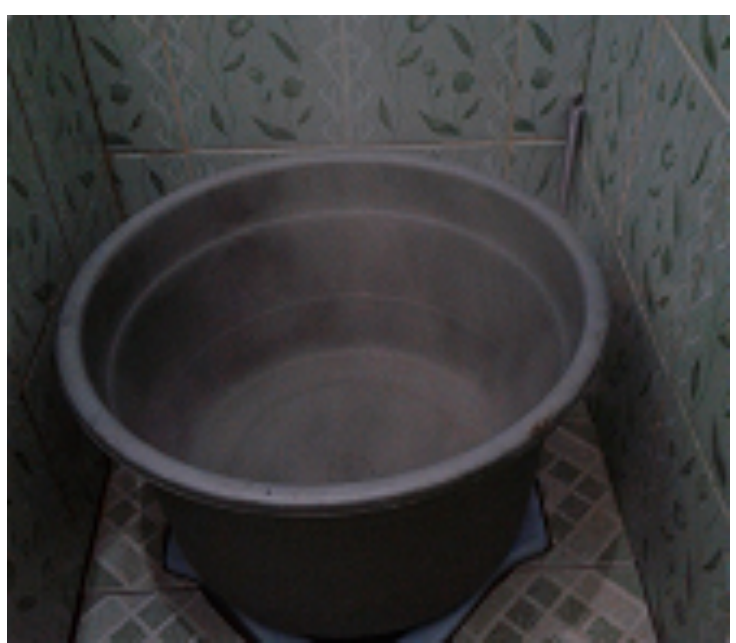

Figure 5 Water to be used for bathing Sando patients (P12)

Sando's Patient (P12) did not allow to be documented as video so the researcher did observation by documenting procedure, bath equipment and therapeutic materials in field note.

The tool category was described with the keyword fabric and pot through the following statements:

"... use fabric and then press it like that ..." (P1 \& 2)

"... with the abis fabric, wipe it off with water ... use

fabric like this, if in the old days use stones ..." (P3)

"... the way to immerse the fabric in hot water then ..." (P4)

"... Hot bath, pressed like this with fabric..." (P5)

"... Ooh, the treatment is using fabric..." (P6)

"... haa fabrics ... wear fabric anyway pressed briefly (P7)

"... that fabric dipped in hot water was put on his mother's body ..." (P8)

"... now just use cloth to take a bath ..." (P9)

"... the stomach is pressed with fabric against all the bodies ... then the fabric that has been dipped in hot water is occupied so that the uterus rises ..." (P10)
"... compulsory care, she uses a sarong or fabric... in the birth canal is pushed with a kick that is superimposed on fabric that has been dipped in hot water ..." (P11)

"... use a fabric or towel to be healthy ... if the mother is not sewn in her birth canal, use fabric like this, then emphasize the whole body ..." (P12)

"... fabric pressed against the whole body ..." (P13)

"... using a fabric that has been dipped in hot water then pressed ..." (P14)

"... if there are no wound suture, then put the fabric pressed into the mother's body ..." (P15)

The participant statement was reinforced by the following triangulation participant statement:

"... making the fabric even the fabric is hard pressed affixed ... the fabric is put in hot water ..." (PT3)

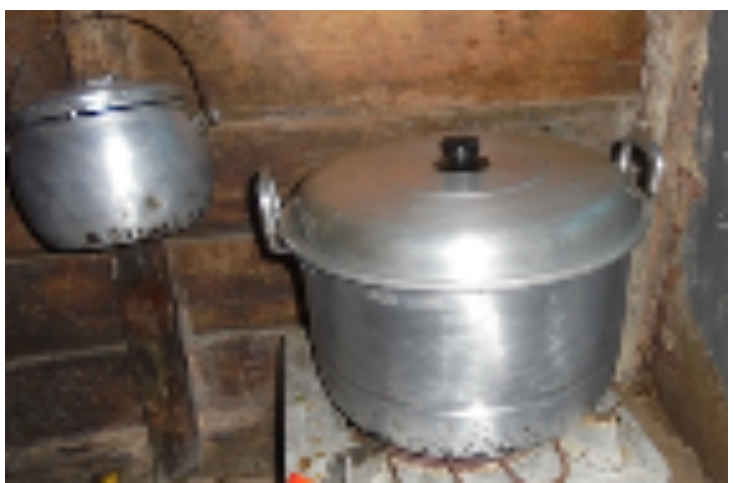

Figure 6 Pot for preparing hot water with a diameter of 35 $\mathrm{cm}$

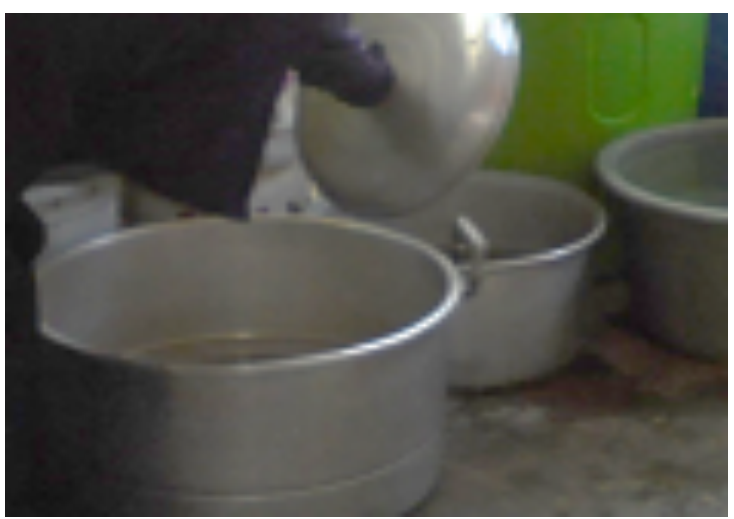

Figure 7 Pot for preparing hot water with a diameter of 35 $\mathrm{cm}$

\section{Prohibition}

The prohibition theme was identified through the restricted area, not bathing, and the impact of breaking the prohibition. The restricted area category was described with the keyword head and suture in the wound through the following statements: 
"...O if the head should not be given hot water when bathing..."(P6)

"...Aa head no, just cold water ha ... later the suture in the wound will come be damaged....(P7)

"...No, it will be finished by pouring cold water on the mother's head, yes you can't, you have to use cold water..." (P8)

“...the mother's head uses cold water ... because now there are seams that can break the suture in the wound later..."(P10)

"...head is not flushed. can't be headed..."(P11)

"... if there is suture in the wound do not be given hot water ..." (P12)

"... if the head cannot be touched by hot water ... but if the suture in the wound it should not be pressed ..." (P13)

"... if there are suture in the wound, just take a bath don't put hot water ..." (P15)

"... the head must not ..." (PT3)

The participant statement was reinforced by the following triangulation participant statement:

"... the head must not flush hot water ..." (PT4)

The impact of breaking the prohibition category was described with the keyword hair fall and removed through the following statements:

"... hot water can cause hair fall, just the face ... (P13)

"... that eee hair is not allowed ... but just here (pointing at face) ... (P3)

"... after the hair was bathed, it was splashed with cold water ... later the suture in the wound can be removed .... (P7)

"... Then that hair can fall out ... (P9)

"... the suturew in the wound will be removed later ..." (P10)

The participant statement was reinforced by the following triangulation participant statement:

"... can cause the hair loss... (PT3)

"... you will lose hair later ... (PT4)

The not bathing category was described with the keyword jaundice and sick through the following statements:

"... usually jaundice, develops to jaundice, pale ..." (p1 \& 2)

"... can people get jaundice ..." (p3)

"... so as not to become sick ..." (P4)

"... can get body aches or sick ..." (P5)

"... get sick, jaiundice, jiaundice, usual headaches, back pain ..." (P6)

"... jaundiice, if people after childbirth but lack of bath therapy ..." (P7)

"... If it's a headache, become sick ..." (P10)

"... yellow or big face ..." (P11)

"... she did not finish bath therapy and finally got jaundice ..." (P13)

"... here, people usually get sick ... take a hot bath so it doesn't turn pale, no jaundice ..." (P14)

The participant statement was reinforced by the following triangulation participant statement:
"... take a hot bath so that the body does not get sick ..." (PT1)

"... so as not to suffer from headaches and sick..." (PT2)

\section{DISCUSSIONS}

\section{Equipment}

The most important material in the hot bath tradition by Muna indigenous midwife is the hot water. Before the delivery was not restricted only in the hospital, the water is heated immediately after giving birth. However, today the hot water is prepared once the mothers arrive at home after returning from the hospital and are ready to receive therapy. The water is prepared by the patient's family, while the indigenous midwife only comes without bringing any tool or materials.

Traditionally, the hot water used by the indigenous midwife is as many as 1 clay pot (a pot with a diameter of $35 \mathrm{~cm}$ ) mixed with cold water as many as $2-3$ buckets. However, these days, the indigenous midwife reduces the temperature of the water as requested by the patient and their family

The patient's family has prepared the place for a hot bath, often in the bathroom or close to the bathroom where mothers can be sufficiently laid down. Subsequently, the indigenous midwife will give a therapy using fabric (or small towel) soaked into the hot water directly using her hands without feeling burnt.

The water is heated through a convectional process by displacing the heat from the metal surface of the pot into the water (Haryadi, 2012; Wibowo, 2015). The heat convection from the water to skin practiced by the indigenous midwife in this present study uses conduction process that affects thermoregulation process in adjusting the normal body temperature and body surface temperature using the fabric or towel to minimize the risk of heat (Kukus, Supit, \& Lintong, 2009; Miyake, 2013). The hot water is commonly used to reduce myalgia and vasodilatation of the blood vessel to treat fatigue and to expedite blood flow in the postpartum mothers (ŚLAGA et al., 2018). 
This present study showed the use of a hot bath in the Muna tribe as a health technology traditionally is based on the culture of the Muna tribe that agrees with physics concerning to the heat transfers and physiological sciences concerning to the adjustment of body temperature and vasodilatation.

\section{Treatment}

Before child delivery in the hospital becomes compulsory, the indigenous midwife could give the hot bath therapy immediately after delivery, within a very short time lag during the water boiling. However, this therapy is now done immediately after the postpartum mothers return from the hospital.

The time lag between delivery and bath therapy is by boiling water in a crock until the placenta is born for about 30 minutes, which is the same as the normal time of delivery of the placenta, the placenta that is not born afterward is called placental retention (Permatasari, Handayani, \& Rachmawati, 2017; Riyanto, 2016). The indigenous midwife patients are reduced because of the obligation of childbirth at a health facility that aims to minimize postpartum complications and even death so that the indigenous midwife will wait for patients to come home from the hospital to be treated (Menteri Kesehatan Republik Indonesia, 2014).

The indigenous midwife's press using hot water in a cloth/fabric is done quickly on the neck, hands, and feet to alleviate the stiffness of the muscles that tighten during the delivery process when producing valsalva maneuvers to push the baby out of the birth canal. The press on the back serves to relieve muscle stiffness due to withstand heavy loads during pregnancy and childbirth. The press on the abdominal area or identical to the uterine area serves to help the blood out immediately and not stuck in the uterine cavity. The face gets similar treatment to avoid swelling due to the process of striking during delivery, especially in the eyes, eyebrows and around the cheek muscles that react the most.

Treatment of the birth canal or vagina area is done with the same tools and materials but in a different way. Press or push is used to perform care on the birth canal so that the reproductive organs of the postpartum mother can return to their normal position, tighten and avoid swelling. Generally, the indigenous midwife expressed her opinion that a hot bath would be healthy, accelerates the recovery process, refreshes and maintains youth.

The benefits of hot water are felt by researchers by conducting trials on researchers themselves to observe the impressions arising from hot bath therapy. Researchers feel the sensation of heat is also a shocking sensation that makes researchers aware to concentrate in taking a deep breath every time the beat of heat pressure is given and ends with a fresh feeling both in the body and mind.

Hot water hydrotherapy provides benefits in relieving muscle stiffness or spasm, pain, and even injury to muscles through the gate control process (Andreinie, 2016; Nurjanah, 2016). Hot water has been shown to stimulate nerves which cause a relaxed sensation and trigger vasodilation of blood vessels so that blood flow in the body is smooth (Edy Prananto, 2016; Nopriani, Primanda, \& Makiyah, 2018; ŚLAGA et al., 2018). Increased oxygen supply followed by vasodilation of blood vessels and muscle relaxation is a cause of health and fitness for postpartum mothers in the Muna tribe.

Similar research carried out on the Butonese who have a close kinship with the Muna Tribe showed the results that a hot bath can be healthy and refreshing for the postpartum mother body (Usman \& Sapril, 2018). Warm compress water therapy has been proven to reduce delivery pain in a study by repairing oxygen-deficient tissue so that muscles can relax (Andreinie, 2016). In contrast, other studies have shown that cold water therapy can relieve perineal pain due to delivery (Girsang et al., 2019; ŚLAGA et al., 2018).

Previous research has shown the importance of care during the postpartum as mothers are susceptible to infection due to injury to the birth canal so that it becomes a pathway for bacteria (Jambi). The indigenous midwife's statement 
that if she does not undergo bathing after giving birth is supported by research on health problems such as urinary tract infections, even puerperal sepsis due to poor personal hygiene (Chepchirchir, Nyamari, \& Keraka, 2017).

The indigenous midwives set different times in determining the obligation of hot bath therapy. On average, they said 4-time-therapy in 2 days, 1 time in the morning and 1 time in the afternoon is a sufficient schedule. But some explained that the time measured for 1 week is better for maternal health. The indigenous midwives have the wisdom of belief that she cannot set prices for her services even though she stays for 1 week or more because her main principle of being an indigenous midwife is to help others. If the rewards are given sincerely, it will make it a long life. The indigenous midwife's values and beliefs also influence the implementation of therapy as a form of surrender of his efforts to God and the existence of special prayers can make her immune from the heat of the water. Postpartum mothers will then do hot bath therapy themselves until even for 30 days.

The period of the hot bath therapy carried out by the indigenous midwives has similarities with the phases of the lochia release. The lochia that comes out within a span of 3 days is lochia rubra with a dark red color that tends to be blackish, the lochia serosa comes out from day 4 to day 10 in brownish pink (pinkish brown), lochia alba comes out after day 10 in yellowish (Kumar, Thakur, Bhawani, Kanga, \& Ranjan, 2016; Ricci \& Kyle, 2009). A woman will not only experience changes in her reproductive organs but also throughout the body especially the body's adaptation to fluid and blood metabolism (Kumar et al., 2016).

\section{Prohibition}

The hot bath therapy does not allow to bath the head with hot water as it can cause the hair to fall. While for the patients with suture wounds in the perineum and cesarean section are prohibited to receive hot bath therapy as it can damage the wound. The indigenous midwives suggest all postpartum mothers have the hot bath therapy otherwise they will be sick and pale like jaundice. Meanwhile, the therapy does not apply to the suture wound.

These prohibitions agree with a study that explains that vaginal care with a suture wound must be done gently to prevent rupture and mother with caesarean section wound must move slowly and avoid strong movement (Ahmed, 2015; Women's and Men's Health Physiotherapy Team, 2016). The postpartum mothers often experience anemia and look pale due to the accumulation of fatigue during pregnancy and excessive fluid excretion during the delivery process as well as postpartum therapy (Khatun et al., 2018; Milman, 2011; Wambach, Mathers, \& Huang). The previous study found that the heat can damage the hair (Dias, 2015).

\section{CONCLUSION}

This present study concludes that the health technology of the Muna tribe that has been done for generations is beneficial for public health care. The hot bath therapy of the Muna tribe has been tested empirically for years. This therapy can relax muscles, expedite the blood flow, and prevent postpartum depression. The health practitioners should be more open to ethnocaring as a part of the local wisdom of Indonesian. Scientific research and review can be made to understand the association between traditional and modern medical review.

Declaration of Conflicting Interest

All authors have declared that there is no conflict of interest for this study.

Acknowledgment

The present study was supported by the Ditjen Penguatan Riset dan Pengembangan Kemenristekdikti.

\section{REFERENCES}

Afiyanti, Y., \& Rachmawati, I. N. (2014). Metodologi penelitian kualitatif dalam riset keperawatan. Jakarta: PT Raja Grafindo.

Ahmed, H. M. (2015). Post episiotomy care instructions among midwives in Kurdistan region, Iraq. Zanco Journal of Medical Sciences, 19(2), 1005-1010. 
Andreinie, R. (2016). Analisis efektivitas kompres hangat terhadap penurunan nyeri persalinan. Paper presented at the prosiding seminar nasional \& internasional.

Chepchirchir, M. V., Nyamari, J., \& Keraka, M. (2017). Associated factors with puerperal Sepsis among reproductive age women in Nandi County, Kenya.

Corey, E., \& Thapa, S. (2011). Postpartum depression: An overview of treatment and prevention. World Health Organization. Department of Reproductive Health and Research, Geneva.

Diah Indriastuti, T. (2015). Deteksi postnatal depression menggunakan Edinburg Postnatal Depression Scale (EPDS) pada kunjungan rumah ibu post partum. Paper presented at Seminar nasional keperawatan komunitas "peran perawat dalam pelayanan kesehatan primer mепијu masyarakat ekonomi asean."

Dias, M. F. R. G. (2015). Hair cosmetics: an overview. International Journal of Trichology, 7(1), 2.

Edy Prananto, A. (2016). Pengaruh masase kaki dan rendam air hangat pada kaki terhadap penurunan insomnia pada lansia. Universitas Muhammadiyah Surakarta,

Fatmawati, D. A. (2015). Faktor risiko yang berpengaruh terhadap kejadian postpartum blues. Eduhealth, $5(2)$.

Fitrianti, Y., \& Angkasawati, T. J. (2015). Pengobatan Tradisional Gayo Untuk Ibu Nifas. Buletin Penelitian Sistem Kesehatan.18(2), 111-119.

Girsang, B. M., Darti, N. A., Simamora, R., \& Karo, E. I. (2019). Gambaran karakteristik luka perineum pada ibu post partum dengan hidroterapi sitz bath. Jurnal Keperawatan Respati Yogyakarta, 6(3), 666-671.

Gutira, T., \& Nuryanti, L. (2010). Hubungan antara dukungan keluarga dengan keadilan baby blues syndrome pada ibu post secno caesaria. Indigenous: Jurnal Ilmiah Psikologi.

Haryadi, M. (2012). Buku ajar perpindahan panas. Bandung: Politeknik Negeri Bandung.

Jambi, U. A. Kota Jambi Tahun 2018.

Khatun, F., Lee, T. W., Rani, E., Biswash, G., Raha, P., \& Kim, S. (2018). The relationships among postpartum fatigue, depressive mood, self-care agency, and self-care action of first-time mothers in Bangladesh. Korean Journal of Women Health Nursing, 24(1), 49-57.

Kukus, Y., Supit, W., \& Lintong, F. (2009). Suhu tubuh: homeostasis dan efek terhadap kinerja tubuh manusia. Jurnal Biomedik, 1(2).

Kumar, R., Thakur, S., Bhawani, R., Kanga, A., \& Ranjan, A. (2016). Clinical profile of scrub typhus in pregnancy in sub-Himalayan region. The Journal of Obstetrics and Gynecology of India, 66(1), 82-87.

Kurniasari, D., \& Astuti, Y. A. (2015). Hubungan antara karakteristik ibu, kondisi bayi dan dukungan sosial suami dengan postpartum blues pada ibu dengan persalinan SC di Rumah Sakit Umum Ahmad Yani Metro Tahun 2014. Holistik Jurnal Kesehatan, 9(3).
Kusumasari, R. V. (2018). Kelelahan postpartum antara ibu primipara dan multipara di wilayah kerja Puskesmas Piyungan Kabupaten Bantul: Comparative Study. Health Sciences and Pharmacy Journal, 2(1), 16-21.

Marzuki, I. Kepercayaan terhadap kemampuan budaya bengkung dalam meningkatkan produksi air susu ibu pada masyarakat bulukumba. Paper presented at Seminar Nasional: Pangan, Teknologi dan Enterpreneurship, Makassar.

Menteri Kesehatan Republik Indonesia. (2014). Peraturan Menteri Kesehatan Republik Indonesia nomor 97 tahun 2014 tentang pelayanan kesehatan masa sebelum hamil, masa hamil, persalinan, dan masa sesudah melahirkan, penyelenggaraan pelayanan kontrasepsi, serta pelayanan kesehatan seksual.

Milman, N. (2011). Postpartum anemia I: definition, prevalence, causes, and consequences. Annals of Hematology, 90(11), 1247.

Miyake, Y. (2013). Pathophysiology of heat illness: thermoregulation, risk factors, and indicators of aggravation. JMAJ, 56(3), 167-173.

Nasri, Z., Wibowo, A., \& Ghozali, E. W. (2018). Faktor determinan depresi postpartum di kabupaten lombok timur. Buletin Penelitian Sistem Kesehatan, 20(3), 89-95.

Nopriani, Y., Primanda, Y., \& Makiyah, S. N. N. (2018). Efektivitas kombinasi relaksasi otot progresif dan rendam kaki air hangat terhadap tekanan darah penderita hipertensi. Dinamika Kesehatan Jurnal Kebidanan Dan Keperawatan, 9(2), 627636.

Nurjanah, S. (2016). Keefektifan kombinasi terapi panas dan dingin dengan terapi panas, terapi dingin terhadap cedera otot hamstring. Retrieved from http://journal.student.uny.ac.id/ojs/index.php/ik ora/article/viewFile/3675/3337

Oktiriani, I. (2017). Perilaku baby blues syndrome pada ibu pasca melahirkan di Kelurahan Sekaran, Kecamatan Gunung Pati. Universitas Negeri Semarang,

Osma, J., Suso-Ribera, C., Martínez-Borba, V., \& Barrera, A. Z. (2020). Content and format preferences of a depression prevention program: A study in perinatal women. Anales De Psicología/Annals of Psychology, 36(1), 56-63.

Permatasari, F. A., Handayani, S., \& Rachmawati, E. (2017). Faktor-Faktor yang berhubungan dengan kejadian perlengketan plasenta (retensio placenta) di Rumah Sakit Islam Jakarta Cempaka Putih: Sebuah Studi Kasus Kontrol. ARKESMAS (Arsip Kesehatan Masyarakat), 2(1), 102-108.

Prastiwi, R. S. Pengobatan tradisional (jamu) dalam perawatan kesehatan ibu nifas dan menyusui di kabupaten tegal. Jurnal Siklus.7(1), 263-267.

Rahayu, I. S., Mudatsir, M., \& Hasballah, K. (2017). Faktor budaya dalam perawatan ibu nifas. Jurnal Ilmu Keperawatan, 5(1), 36-49.

Ricci, S. S., \& Kyle, T. (2009). Maternity and pediatric nursing: Lippincott Williams \& Wilkins. 
Riyanto, R. (2016). Faktor risiko kejadian retensio plasenta pada ibu bersalin di RSUD Dr. H. Bob Bazar, Skm Kalianda. Jurnal Kesehatan Metro Sai Wawai, 8(1), 38-44.

Saputri, R. A., Rahayu, H. S. E., \& Sri, M. (2016). Hubungan konsumsi asam lemak omega 3 dengan postpartum blues pada ibu postpartum di Rumah Sakit Aisyiyah Muntilan tahun 2014. Journal of Holistic Nursing Science, 3(1), 3043.

Siswanto, S., \& Suyanto,. (2017). Metodologi penelitian kombinasi kualitatif-kuantitatif kedokteran dan kesehatan. Yogyakarta: Bosscript

Ślaga, J., Gizińska, M., Rutkowski, R., Raglewska, P., Balkó, Š., \& Straburzyńska-Lupa, A. (2018). Using hydrotherapy at different temperatures for promoting recovery in professional athletes. Trends in Sport Sciences, 25(2).

Thurgood, S., Avery, D. M., \& Williamson, L. (2009). Postpartum depression (PPD). American Journal of Clinical Medicine, 6(2), 17-22.

Usman, U., \& Sapril, S. (2018). Pemanfaatan budaya posoropu dalam perawatan masa nifas oleh perempuan Buton Utara. Media Kesehatan Masyarakat Indonesia Universitas Hasanuddin, 14(3), 268-277.
Wambach, Y.-L. K. K., Mathers, N., \& Huang, Y.-C. A Comparison of Taiwanese and American Breastfeeding Mothers' Self-reported Problems at Three Weeks Postpartum.

Wibowo, A. (2015). Perpindahan panas pada heat exchanger dobel pipa dengan sirip ber bentuk siku empat. ENGINEERING, 10(1).

Wijaya, B. A., \& Arum Pratiwi, S. K. (2017). Hubungan dukungan keluarga dengan tingkat depresi pada ibu postpartum di Poliklinik Obsgyn Rumah Sakit Umum Daerah Dr. Moewardi. Universitas Muhammadiyah Surakarta,

Women's and Men's Health Physiotherapy Team. (2016). our recovery after childbirth: physiotherapy, exercises and advice. Retrieved from http://www.somethingfishy.org/reach/toolbox.p $\underline{\mathrm{hp}}$

Cite this article as: Indriastuti, D., Tahiruddin. Hot bath therapy for postpartum mothers: The ethnocaring practice in the Muna Tribe, Southeast Sulawesi, Indonesia. Public Health of Indonesia. 5(4),105-115. 